\title{
Fisketillatelser og pant - lovfesting av den rettslige løsningen i «Barents Eagle»?
}

\section{Innledning ${ }^{12}$}

I kjølvannet av struktureringen av den norske fiskeflåten ved bruk av privatfinansierte kondemneringsordninger har fiskernes gjeld knyttet til kvotekjøp økt. ${ }^{3}$ Ordningene går kort fortalt ut på at kvoten til et fartøy overføres til et annet fartøy gjennom en privatrettslig avtale når det foreligger samtykke fra fiskerimyndighetene til transaksjonen. ${ }^{4}$ Samtykke kan bare gis hvis avgiverfartøyet tas permanent ut av fisket (kondemneres) og oppgir sine tillatelser. Det er med andre ord tale om markedsbaserte ordninger for tilpassing av flåten til ressursgrunnlaget. ${ }^{5}$ Dette betegnes som «strukturering». ${ }^{6}$

Kvotene i de ervervsmessige fiskerier har i dag en betydelig verdi som følge av deres omsettelighet, varighet og eksklusivitet samt den notoritet og publisitet som er sikret gjennom

\footnotetext{
${ }^{1}$ Forfatteren takker

${ }^{2}$ Denne artikkelen er basert på innlegg på to seminarer. Det dreier seg om et seminar i regi av Norges Råfisklag og K.G. Jebsen-senter for havrett ved UiT den 19. september 2018 og et seminar i regi av UiT, Det juridiske fakultets formuerettsgruppe og Nordisk institutt for sjørett, UiO den 3. oktober 2018. Begge seminarer ble holdt i Tromsø.

${ }^{3}$ Se Fiskeridirektoratets lønnsomhetsundersøkelser for fiskeflåten https://www.fiskeridir.no/Yrkesfiske/Statistikk-yrkesfiske/Statistiskepublikasjoner/Loennsomhetsundersoekelse-for-fiskefartoey (besøkt 11. desember 2018). Undersøkelsene fra 2004-2013 viser at gjennomsnittlig kortsiktig og langsiktig gjeld i flåten har $ø k t$ siden 2004, og at den økte gjeldsbelastningen kan knyttes til kvoteverdier, se D. Standal og F. Asche, «Hesitant reforms: The Norwegian approach towards ITQ's», Marine Policy 88 (2018) s. 58-63, på s. 61 høyre spalte. Disse forfatterne fremhever videre: «However, more of the fishing firms' total capital consists of fish quotas that have been purchased, reflecting the monetization of the value of fish quotas.» Direktoratets seneste undersøkelser viser den samme utviklingen som vi ser i perioden 2004-2013. Se undersøkelsen fra 2016, s. 33.

${ }^{4}$ Forskrift 7. november 2003 nr. 1309 om spesielle kvoteordninger for kystfiskeflåten og forskrift 4. mars 2005 nr. 193 om strukturkvoteordning mv. for havfiskeflåten.

${ }^{5}$ Audun Iversen mfl., Nofima rapport 8/2018, Strukturering i fiskeflåten-Drivkrefter og konsekvenser, s. $20 \mathrm{flg}$.

${ }^{6}$ Se for eksempel NOU 2016: 26 Et fremtidsrettet kvotesystem, kapittel 6 Strukturkvoteordningen (s. 43 flg.), St.meld. nr. 21 (2006-2007) Strukturpolitikk for fiskeflåten, og NOU 2005: 10 Lov om forvaltning av viltlevende marine ressurser, punkt 7.8 Strukturordninger (s. 135-137).
} 
skipsregisteret og fiskerimyndighetenes register over norske fiskefartøy mv. ${ }^{7}$ I mange tilfeller er enkeltfartøys kvoter betydelig mer verdt enn fartøyet i seg selv. ${ }^{8}$ Målestokken for kvoteverdien er «hvor mye en fisker er villig til å betale for retten til å fiske». ${ }^{9}$ Bent Magne Dreyer beskriver strukturkvoteordningene slik:

«Ordningene har virket. Vi har i dag langt færre fartøy og fiskere som har fått en stadig mer eksklusiv tilgang til fiskeressursene. Ressursforvaltningen gir høye kvoter som har stor kommersiell verdi. Lukkingen gjør at de få som er igjen, er beskyttet mot at nye og 'plagsomme' aktører kommer inn i fiskeriene. Dermed er den andre betingelsen - eksklusiv og beskyttet tilgang for enkeltbedrifter - til stede for å høste ressursrente i deler av de norske fiskeriene.

Effekten er godt synlig. Av regnskapene til store deler av fangstleddet framgår det at lønnsomheten er høy. I tillegg har samling av kvoter på enkeltfartøyer bidratt til at stordriftsfordeler i fangstoperasjonen realiseres i større grad enn tidligere. Markedet for strukturkvoter har samtidig, gjennom kvoteprisene som i dag oppnås, vist at investorer verdsetter en slik eksklusiv tilgang svært høyt. En viktig indikator for høy lønnsomhet, og at bankene er fornøyde med sikkerheten, er at det er investert i mange nye og påkostede fiskefartøy.» ${ }^{10}$

I den seneste forskningsrapporten om struktureringen av fiskeflåten slås det fast at «sikkerhet og panteverdi av kvotene [har] hatt stor betydning for finansieringsevnen». ${ }^{11}$ Det synes videre å være et standard vilkår i låneavtaler om finansiering av kvotekjøp at verdien av fiskerettighetene

\footnotetext{
${ }^{7}$ Svein Kristian Arntzen, «Strukturkvotetillatelser som formuesgoder», i Tore Henriksen og Øyvind Ravna (red.), Juss i Nord: Hav, fisk og urfolk - En hyllest til Det juridiske fakultet ved Universitetet i Tromsøs 25-årsjubileum, s. 121-135.

${ }^{8}$ Se for eksempel Hålogaland lagmannsretts dom LH-2016-22398.

${ }^{9}$ Audun Iversen, forsker ved Nofima, Fiskeribladet Fiskaren, 8. oktober 2018, side 2.

${ }^{10}$ Bent Magne Dreyer, forskningssjef ved Nofima, «Jakta på ressursrenten», Norsk fiskerincering, nr. 8 2018, og https://nofima.no/mening/jakta-pa-ressursrenten/.

${ }^{11}$ Iversen mfl., op.cit., s. 40.
} 
inngår i fartøypantet. ${ }^{12}$ For ordens skyld tilføyes at med kvoter forstås i realiteten kvotefaktorer. Disse gir uttrykk for enkeltfartøys ideelle andel av gruppekvoten i det aktuelle fiskeriet. ${ }^{13}$ Spørsmålet om pant i fartøyet omfatter verdien av fiskefartøyets fisketillatelser, ble avgjort av Høyesterett i Rt. 2009 s. 1502 «Barents Eagle». Thor Falkanger har oppsummert dommens anførte ratio decidendi slik:

«- tillatelsene representerer en økonomisk økonomiske verdi, - denne kan ikke betegnes som et selvstendig formuesgode, - tillatelsene er knyttet til fartøyet på en slik måte at pant $i$ fartøyet omfatter den verdi som ligger i tillatelsene». ${ }^{14}$

I det følgende drøftes om den rettslige løsningen i «Barents Eagle» bør lovfestes. Videre om den danske lov 16. mars 1994 nr. 170 sølov $§ 47$ Stk. 4-8, innført i søloven ved lov 7. juni 2006 nr. 526, kan vise vei. ${ }^{15}$ Bestemmelsen slår blant annet fast at rettigheter i et skip som er registrert $i$ det danske skipsregisteret, omfatter fiskerettigheter som er tildelt eieren i egenskap av eier av skipet eller som senere erverves av denne til bruk for skipet. For ordens skyld tilføyes at Gunnar Eriksen i en artikkel fra 2009 med klar referanse til tillatelsene i de ervervsmessige fiskerier har tatt til orde for å bringe «hjemmelen for å pantsette formuesgoder som har vist seg svært omsettelige» i orden. ${ }^{16}$

Tilnærmingen til spørsmålet om lovfesting av løsningen i «Barents Eagle» kan ved første betraktning begrenses til en konstatering av at lovfesting vil bidra til demokratisk legitimitet gjennom lovgivningsprosessen og rettssikkerhet i form av forutberegnelighet. Det gjør seg imidlertid gjeldende ytterligere forhold som har sammenheng med at fiskerisystemet med sine

\footnotetext{
${ }^{12}$ Se for eksempel bankens anførsel i Rt. 2009 s. 1502 «Barents Eagle» avsnitt 39, og Høyesteretts vurdering av det avtalerettslige forholdet mellom långiver og låntaker i denne saken i avsnitt 5860.

${ }^{13}$ Se for eksempel forskrift 4. mars $2005 \mathrm{nr}$. 193 om strukturkvoteordning mv. for havfiskeflåten og de årlige reguleringsforskrifter for lukkede grupper. Det vil si grupper som krever spesiell tillatelse eller deltakeradgang, jf. lov 26. mars $1999 \mathrm{nr} .15 \mathrm{om}$ retten til å delta i fiske og fangst (deltakerloven) $\S \S 12$ og 21. Fordeling av den nasjonale kvote på gruppe- og fartøynivå er regulert i lov 6. juni $2008 \mathrm{nr}$. 37 om forvaltning av viltlevande marine ressursar (havressurslova) $\S 11$ annet ledd og § 12. Se også NOU 2016: 26, s. 29-34.

${ }^{14}$ Thor Falkanger, «Fiske og pant - Om pant i verdier som inngår i kommersielt fiske», MarIus 489, 2017.

${ }^{15}$ Lov 7. juni $2006 \mathrm{nr}$. 526 om ændring af søloven og forskellige andre love (Digital skibsregistrering, pant, udlæg m.v. i fiskerirettigheder, fordeling af bjærgeløn og skibes hjemsted)

${ }^{16}$ Gunnar Eriksen, «Omsettelighet som vilkår for gyldig pant», i Jon Petter Rui (red), Rettshjelp fra kyst til vidde - Festskrift til Jusshjelpa i Nord-Norge 20 år 2009, s. 115-128.
} 
forvaltnings- og sanksjonsregler er en innovasjon i stadig endring, blant annet som følge av endrede fiskeripolitiske målsettinger. ${ }^{17}$ Et sentralt spørsmål er derfor om det har funnet sted regelendringer i tiden etter «Barents Eagle». Det vil si endringer som gjør det mulig å tale om et annet typetilfelle $\mathrm{i}$ dag enn tilfellet som er lagt til grunn av Høyesterett $\mathrm{i}$ «Barents Eagle», og som vil gi en annen subsumsjon enn det som ble resultatet i denne dommen. Et annet spørsmål er om det er rom for fortsatt kapasitetsnedbygging i flåten etter de gjeldende regler for oppsamling av kvoter på enkeltfartøy. I tilfelle indikeres et vedvarende behov for tilgang til kreditt. I tilknytningen til begge spørsmål vil jeg også se nærmere på kvoteutvalgets forslag i NOU 2016: 26 om endring av fiskerisystemet. Utredningen peker nemlig i retning av fortsatt effektivisering av fiskeflåten.

Opplegget i det følgende er at jeg starter med spørsmålet om kapasitetsreduksjon. Dermed gis det også en kortfattet innføring i den økonomiske tenkning om kapasitetstilpassing. Etter dette ses det på gjennomførte og foreslåtte endringer i fiskerisystemet, og gis en vurdering. Det redegjøres så for søloven $\S 47$ og det danske fiskerisystemet. Artikkelen avsluttes med en avsluttende merknad.

\section{Kapasitetsreduksjon}

\subsection{Teknisk og økonomisk kapasitetsreduksjon}

Når det tales om kapasitet i fiskeflåten er det viktig å skille mellom kapasitetsreduksjon gjennom reduksjon av antallet fartøy (teknisk kapasitetsreduksjon) og økonomisk kapasitetstilpassing. ${ }^{18}$ Med økonomisk kapasitetstilpassing forstås tilpassing av flåtens kapasitet for å oppnå størst økonomisk utbytte. ${ }^{19}$ Slik tilpassing krever at en rekke faktorer vurderes. Her kan pekes på at vi står overfor ulike fiskearter og skalldyr, ulike fangstområder, ulike typer fartøy og redskap.

\subsection{Fortsatt kapasitetsreduksjon?}

Ved å redusere antallet fartøy i flåten oppnås større effektivitet. Effektivisering er viktig for å opprettholde lønnsnivået for de som arbeider i flåteleddet. Men effektivisering kan også være ønskelig for å hente ut mest mulig ressursrente av fiskeriene. Ressursrenten er den superprofitt som kan oppnås når det

\footnotetext{
${ }^{17}$ Se i denne forbindelse Kjellrun Hiis Hauge mfl. (red.), Comparative Evaluations of Innovative Fisheries Management - Global Experiences and European Prospects, 2009.

${ }^{18}$ NOU 2016: 26, s. 25. Iversen mfl., op.cit., s. 14 flg.

${ }^{19}$ NOU 2016: 26, s. 25.
} 
høstes av en godt forvaltet fiskeressurs av stor økonomisk verdi. Ved å ta markedsverdien av produktet og trekke fra produksjonskostnadene for alle innsatsfaktorer fremkommer ressursrenten. I dette regnestykket inngår selvsagt også kostnader til arbeidskraft og alternativ avkastning på kapitalen. ${ }^{20}$ Betegnelsen «superprofitt» relaterer seg altså til «fortjeneste utover det arbeidskraft og kapital vil få betalt $\mathrm{i}$ annen næringsvirksomhet». ${ }^{21}$ Det er i dag delte meninger om ressursrentebeskatning. Audun Iversen sier det slik:

«Ressursrentebeskatning er en politisk nøtt. Og for oss er det faglig interessant, nettopp fordi det ikke finnes noen enkel løsning på det uføret vi har satt oss i: Det er ikke enkelt med ressursrentebeskatning når mye av ressursrenten er privatisert, og hentet ut av næringen.» ${ }^{22}$

Forfatteren sikter her til at «ressursrenten i mange tilfeller er hentet ut, innkassert av dem som har solgt seg ut». ${ }^{23}$ Kvoteutvalget legger også til grunn at «deler av den forventede fremtidige ressursrenten allerede er kapitalisert på [kvote]selgers hånd gjennom salgsverdien». ${ }^{24}$ Utvalget mener imidlertid at det $\mathrm{i}$ kjølvannet av effektivisering av kvotesystemet i tråd med flertallets forslag bør «innføres en form for innkreving av ressursrenten i fiskeriene». ${ }^{25}$

Situasjonen i dag er ifølge forskere ved Nofima at det fortsatt er rom for strukturering og kapasitetsnedbygging i flåteleddet. Dette gjelder så vel innenfor gjeldende regelverk som ved fjerning av dagens begrensninger vedrørende struktureringsgrad. ${ }^{26}$ Struktureringsmuligheten innenfor dagens regelverk indikerer et vedvarende behov for kreditt til finansiering av kvotekjøp. Usikkerhet om hvorvidt pant i fartøyet omfatter fisketillatelsenes økonomiske verdi, er i denne situasjon uheldig først og fremst fordi det er fare for at oppfyllelsen av den fiskeripolitiske målsetting om strukturering av flåten ikke finner sted eller bremses. Det er altså en risiko for at kapitalmarkedet ikke fungerer effektivt, ved at prosjekter ikke får finansiering selv om disse vurderes «å gi tilstrekkelig forventet risikojustert lønnsomhet», eller ved at finansiering oppnås, men at det ikke gis «tilgang til den ønskede eller rette typen kapital eller kapital på ønsket tidspunkt»». ${ }^{27}$

\section{Endringer i fiskerisystemet i tiden etter «Barents Eagle»?}

\footnotetext{
${ }^{20}$ NOU 2016: 26, s. 65.

${ }^{21}$ NOU 2005: 10, s. 131.

${ }^{22}$ Iversen, Fiskeribladet Fiskaren, 8. oktober 2018, side 2.

${ }^{23} 1 . c$. .

${ }^{24}$ NOU 2016: 26, s. 67.

${ }^{25}$ NOU 2016: 26, s. 100.

${ }^{26}$ Iversen mfl., op.cit., kapittel 4 og 5.

${ }^{27}$ NOU 2018: 5 Kapital i omstillingens tid, s. 15.
} 


\section{1 «Barents Eagle»}

Her vil jeg starte med å si noen ord om denne dommen. Konkursboet etter trålerrederiet Barents Eagle mente at bankens avtalepant i tråleren ikke omfattet verdien av fiskerettighetene som et aksessorium til fartøyet, men at fiskerettighetene måtte anses som et formuesgode som det etter det panterettslige legalitetsprinsippet kreves hjemmel i lov for å kunne pantsette. Boet fikk ikke medhold. Det sentrale i Høyesteretts argumentasjon var, som antydet innledningsvis, at verdien av fartøyets tillatelser i omsetningssammenheng ikke kan skilles fra fartøyet. Thor Falkanger har i sin artikkel påpekt at det er svakheter i Høyesteretts argumentasjon på dette punktet. Kritikken knytter seg til avsnitt 63 som lyder slik:

«Det kan riktignok hevdes at adgangen etter regelverket til å foreta utskifting av fartøy og til å føre fisketillatelsen over på et erstatningsfartøy, se bl.a. forskriften av 13. oktober 2006 nr. 1157 § 1-3, innebærer at fartøy og fisketillatelse ikke kan ses på som uatskillelige. Jeg er likevel kommet til at den verdi som tillatelsen representerer, i omsetningssammenheng ikke kan skilles fra det formuesgode som tillatelsen knytter seg til, men må anses som en del av dette, se slik også Skoghøy, Panterett 2. utg. side $39-40 .{ }^{28}$ (mine uthevelser)

Falkanger mener at Høyesterett i dette avsnittet ikke gir noen begrunnelse for hvorfor fiskerettigheter likevel må anses som aksessorium til fartøyet når det vitterlig forholder seg slik at disse kan overføres uavhengig av fartøyet. ${ }^{29}$ Riktignok er det i Høyesteretts argumentasjon en henvisning til Jens Edvin A. Skoghøy, men dommens anførte ratio decidendi er like fullt at fiskerilovgivningen begrenser omsetteligheten av enkeltfartøys høstingsmuligheter.

\subsection{Endringer i fiskerisystemet i tiden etter «Barents Eagle»}

I tillegg til svakheten i Høyesteretts argumentasjon, som Falkanger påpeker, er det etter endringen av deltakerloven $\S 17$ i 2015 blitt enda klarere at synet på fisketillatelser som aksessorium til fartøyet ikke er helt treffende. ${ }^{30}$ Paragraf 17 ble endret fordi ingen av de eksisterende ordningene for overføring av tillatelser «åpner for at et fartøy kan overta en tillatelse fra et fartøy i et annet rederis eie uten at rederiet

${ }^{28}$ Rt. 2009 s. 1502 «Barents Eagle» avsnitt 63. Forskriften det vises til her, er konsesjonsforskriften slik denne lød før endringen i 2015. Forskrift 13. oktober 2006 nr. 1157 om spesielle tillatelser til å drive enkelte former for fiske og fangst (konsesjonsforskriften).

${ }^{29}$ Falkanger, op.cit., s. 37.

${ }^{30}$ Deltakerloven $\S 17$ ble endret ved lov 19. juni 2015 nr. 78 med ikrafttredelse 1. juli 2015, jf. res. 19. juni 2015 nr. 692. 
også kjøper fartøyet og deretter søker om tildeling». ${ }^{31}$ Etter lovendringen åpner $\S 17$ for overføring av spesielle tillatelser (konsesjoner) mellom fartøy i havfiskeflåten uten at fartøyet overdras sammen med tillatelsen. ${ }^{32}$ Erverver av tillatelsen får altså utstedt en ny tillatelse med samme innhold som tillatelsen som oppgis av selger (erstatningstildeling). Ervervet forutsetter fiskerimyndighetenes samtykke. ${ }^{33}$ Den nye tillatelsen knyttes til ett bestemt fartøy. En nokså tilsvarende regulering gjelder også for kystflåten ved overføring av deltakeradganger fra et fartøy til et annet. ${ }^{34}$ Poenget her er altså at fisketillatelsene gis et sterkere preg av formuesgode når disse kan omsettes uavhengig av fartøyet. Denne utviklingen skaper tvil om Høyesteretts forståelse av fiskerisystemet $\mathrm{i}$ «Barents Eagle» fortsatt er uttrykk for gjeldende rett, eller om den rettslige subsumsjonen etter lovendringen vil være en annen.

\subsection{Kvoteutvalget}

Når det gjelder framtidsutsiktene, nevnes at kvoteutvalgets forslag om endring av fiskerisystemet innebærer at fiskerettighetene gis enda sterkere preg av formuesrettigheter. Da tenker jeg ikke bare på den øte grad av omsettelighet og varighet som foreslås for fiskerettighetene. Men også ved å gi rettighetshaverne økt grad av eksklusivitet til fiskeressursene. Jeg skal her gi en oversikt over noen av forslagene: ${ }^{35}$

a. Mens havfiskeflåtens spesielle tillatelser (konsesjoner) er tidsubegrensede, er kystflåtens tillatelser tidsbegrenset til ett år. ${ }^{36}$ Dette skillet foreslås fjernet. ${ }^{37}$ Det foreslås således at det $\mathrm{i}$ de ervervsmessige fiskeriene benyttes en type fisketillatelse for samtlige fartøy i de lukkede fiskeriene. Det vil si en type tillatelse i fartøygrupper hvor det er fastsatt et største antall fartøy som får delta i det aktuelle fisket. Etter endringen vil deltakelse med fartøy i de lukkede gruppene kreve ervervstillatelse og fisketillatelse. For deltakelse i grupper hvor det ikke er fastsatt et største antall tillatte fartøy, vil det være tilstrekkelig med ervervstillatelse. Endringen av en tillatelses varighet har betydning for spørsmålet om denne har et sterkere eller svakere preg av formuesrettighet.

b. Kvoteutvalget foreslår videre at den begunstigede innehaver av en fisketillatelse skal gis større grad av eksklusiv adgang til høsting av fiskeressursene. Etter dagens system fordeles den nasjonale kvote på

\footnotetext{
${ }^{31}$ Prop. 88 L (2014-2015) Endringer i deltakerloven (tildeling av spesiell tillatelse og adgang til å delta i fiske), s. 10.

${ }^{32}$ Se forskrift 13. oktober 2006 nr. 1157 om spesielle tillatelser til å drive enkelte former for fiske og fangst (konsesjonsforskriften).

${ }^{33}$ Se nærmere om vilkårene i Erik Wold Sund og Tore Fjørtoft, «Tillatelser til kommersielt fiske», Tidsskrift for forretningsjus, nr. 1 2018, s. 23-106, på s. 69.

${ }^{34}$ Forskrift 13. desember 2018 om adgang til å delta i kystfartøygruppens fiske og enkelte andre fiskerier for 2019 (deltakerforskriften) $\S 49$.

${ }^{35}$ NOU 2016: 26, kapittel 9 (s. 94 flg.).

${ }^{36}$ Se deltakerloven $\S 21$ første ledd.

${ }^{37}$ NOU 2016: 26, s. 94.
} 
fartøygrupper. Det vil si at selv om et fartøys kvotefaktor i sin gruppe ligger fast, kan fordelingen av den nasjonale kvote mellom gruppene endres. Ved å knytte et fartøys kvotefaktor til den nasjonale kvote fjernes dette handlingsrommet. ${ }^{38}$

c. Utvalget fremmer også en del andre forslag som vil bidra til å styrke de begunstigede fartøys eksklusive rett til høsting av fiskeressursene. Fiskerimyndighetene benytter for eksempel ekstrakvoteordninger for å fremme bestemte formål. Ved enten å fjerne eller sette et tak for slike ordninger, slik kvoteutvalget antyder, gir dette de begunstigede enkeltfartøy økt forutberegnelighet og eksklusivitet. ${ }^{39} \mathrm{Jeg}$ vil også nevne at forslaget om å gjøre de såkalte strukturkvotene tidsuavgrensede er av betydning for enkeltfartøys eksklusive rådighet over ressursene. ${ }^{40}$

d. Til slutt vil jeg nevne forslaget om å åpne for utleie av deler av enkeltfartøys kvoter innenfor kvoteåret på en web-basert markedsplass. ${ }^{41}$ Kvotene skal altså kunne skilles fra enkeltfartøy for en nærmere bestemt periode innenfor kvoteåret, og får derved økt grad av omsettelighet.

\subsection{Vurdering}

Redegjørelsen foran viser at ytterligere strukturering av flåten er mulig innenfor gjeldende regler. Det synes også å kunne legges til grunn at kjøp av strukturkvoter ofte finansieres gjennom lån. Hertil kommer at endringene av fiskerilovgivningen i tiden etter «Barents Eagle» skaper tvil om Høyesteretts forståelse av fiskerisystemet fortsatt er uttrykk for gjeldende rett, eller om den rettslige subsumsjonen etter lovendringen vil være en annen. Det bør også tas i betraktning at kvoteutvalgets forslag indikerer at kvoterettighetene kan få et sterkere preg av formuesrettigheter enn disse har i dag. I denne situasjon er det nærliggende å anbefale at rettslig usikkerhet om verdien av fisketillatelsene omfattes av fartøypantet, elimineres ved ny lovgivning. Det er her den danske søloven $\S 47$ synes å kunne vise vei. Dette ses det nærmere på nedenfor.

For ordens skyld kan tilføyes at alternativet til lovfesting av løsningen i «Barents Eagle» er å åpne for pantsetting av fiskerettigheter uavhengig av fartøyet. For dette alternativet er det nærliggende å benytte akvakulturloven som veiviser. ${ }^{42}$ Men dette alternativet ser jeg ikke nærmere på, fordi fartøyet er og fortsatt vil stå sentralt i fiskeriforvaltningssystemet også for det tilfellet at kvoteutvalgets endringsforslag tas til følge. Samlet pantsetting av fartøy og fiskerettigheter er nok også i de fleste tilfeller det mest praktiske. Hertil kommer at det fremstår som fornuftig å bygge videre på et system som er innarbeidet på næringsfeltet.

${ }^{38}$ NOU 2016: 26, s. 94-95. Her dreier det seg om en endring av havressurslova $\S 11$, annet ledd.

${ }^{39}$ NOU 2016: 26, s. 39.

${ }^{40}$ NOU 2016: 26, s. 97.

${ }^{41}$ NOU 2016: 26, s. 40.

${ }^{42}$ Lov 17. juni 2005 nr. 79 om akvakultur (akvakulturloven) kapittel V. 


\section{Kan søloven $\S 47$ vise vei?}

\subsection{Noen innledende merknader}

Når det danske fiskerisystemet og den rettslige reguleringen av pant i fisketillatelser i dette systemet er trukket frem, skyldes det ikke bare at Danmark i 2006 lovfestet at pant i fartøyet automatisk omfatter verdien av fartøyets tillatelser. Det skyldes også at vårt forvaltningssystem har visse fellestrekk med det danske. Og flere elementer i kvoteutvalgets forslag synes å være en del av det danske systemet. Videre har vi en felles rettskultur. Sist, men ikke minst er sentrale hensyn som ligger til grunn for det danske systemet og kvoteutvalgets forslag, de samme: Innenfor en miljømessig bærekraftig forvaltning av fiskeressursene skal lønnsomheten i flåten tillegges stor vekt. Dette er ikke en ny dreining som kan tilskrives kvoteutvalget. Utvalget beveger seg bare videre i den retningen som departementet har fulgt $\mathrm{i}$ årene før utvalget ble nedsatt. ${ }^{43}$ I en rapport fra 2012 beskrives utviklingen i de danske saltvannsfiskerier slik:

«Danmark er den største fiskerinasjonen i EU, men sektoren spiller likevel en beskjeden rolle i landets totale økonomi. Lokalt har fiskeriene imidlertid hatt stor betydning, særlig for små steder, der utfallet av lokaliseringsspørsmål har vært sentralt for små byers videre utvikling. Dette omhandler ikke bare den økonomiske aktiviteten fisket gir i seg selv, men også den betydningen det har fått for utbygging av infrastruktur og for havner som vanskelig vil kunne overleve uten fiskeriene. Fiskeriene har på denne måten hatt større politisk enn økonomisk betydning.

Dette er imidlertid i ferd med å endre seg fordi fiskeriene nå forvaltes gjennom et system for omsettelige konsesjoner. Dette har ført til konsentrasjon av kvoter, på færre bedrifter og personer og følgelig også steder. Beslutningsnivået har på denne måten endret seg fra å være politisk til å bli mer markedsstyrt. På denne måten styrkes den økonomiske posisjonen til danske fiskerier samtidig som den politiske svekkes. Fiskeriene har blitt mer profesjonalisert og næringsdrevet enn tidligere, der de dårlige blir kjøpt ut og forlater med penger, de som lykkes er gjerne høyt utdannet samtidig som bankene blir mer involverte. Det sies at det blir bedre, men ikke lettere å være fisker i Danmark.» ${ }^{44}$

\footnotetext{
${ }^{43}$ NOU 2016: 26, s. 24.

${ }^{44}$ Petter Holm og Kathrine Tveiterås, «Fiskeripolitikk i bevegelse - Hvilken framtid har det nordiske fiskerisamarbeidet», rapport skrevet på oppdrag fra det norske Fiskeri- og kystdepartementet, Tromsø 2012, s. 26.
} 
Fiskeriforvaltningen er fra 2017 tillagt Udenrigsministeriet ved ministeren for fiskeri- og likestilling og for nordisk samarbeid. Det er videre etablert en selvstendig Fiskeristyrelse under Underrigsministeriet. Deler av den danske fiskerilov administreres av Fødevarestyrelsen. ${ }^{45}$

I det følgende redegjøres det kort for det danske fiskeriforvaltningssystemet og det pekes på noen fellestrekk med utgangspunkt i vårt fiskerisystem og kvoteutvalgets forslag. Deretter presenteres sølovens $\S 47$ samt min anbefaling.

\subsection{Fiskerisystemet og fellestrekk}

a. Omsettelige kvoteandeler. Det sondres mellom individuelle omsettelige kvoteandeler (IOK) og fartøykvoteandeler (FKA). I Udenriksministeriets Bekentgørelse om regulering af fiskeriet i 2014-2020 slås det fast at FKA er andeler av den nasjonale kvote, som kan høstes, medbringes og landes av et konkret fartøy, og som eierne kan overføre helt, eller under visse betingelser delvis, til andre fartøy. ${ }^{46}$ IOK defineres på samme måte, men med en viktig forskjell. Det indikeres nemlig at adgangen til delvis overføring av kvoteandeler er større for IOK enn for FKA. ${ }^{47}$

I Bekentgørelsen tales det også om eierandeler. Dette er den andel av den nasjonale kvote en person råder over gjennom helt eller delvis eierskap til ett eller flere fiskefartøy, eller via helt eller delvis eierskap av selskaper som eier fiskefartøy. ${ }^{48}$ Denne eierskapsdefinisjonen knytter seg til reglene om kvotekonsentrasjon. Det vil si regler som begrenser hvor stor andel av den nasjonale kvote som kan samles på en hånd, direkte eller indirekte.

Innenfor reglene om kvotekonsentrasjon er adgangen til omsetning av kvoteandeler stor, både på permanent basis og innenfor et kalenderår, for IOK og FKA. De største begrensningene gjelder for FKA. For disse er det for eksempel i Bekentgørelse 2014-2020 bestemt at inntil 25\% av et fartøys FKA etter samtykke fra fiskerimyndighetene kan overføres innenfor kalenderåret. ${ }^{49}$ Dermed indikeres en viss

\footnotetext{
${ }^{45}$ Se Dansk Karnov, 11.08.2018 Kommentarer til lov om fiskeri og fiskeopdræt (fiskeriloven), jf. lovbekentgørelse nr. 17 af 4. januar 2017 ved Elsbeth Teichert, konsulent, NaturErhvervstyrelsen: «Fiskeriområdet er ved kgl res af 2017-08-07 blevet udskilt af Miljø- og Fødevareministeriet og overført til ministeren for fiskeri og ligestilling og for nordisk samarbejde, hvorefter fiskeriområdet, herunder EU-samarbejdet om fiskeripolitikken, håndteres departementalt $\mathrm{i}$ Udenrigsministeriet. Der er etableret en selvstændig Fiskeristyrelse under Udenrigsministeriet. Dele af loven administreres af Fødevarestyrelsen, jf. bkg 2017 1523.»

${ }^{46}$ BEK nr. 1604 af 19/12/2017 § 13 nr. 14 sammenholdt med nr. 31.

${ }^{47}$ BEK nr. 1604 af 19/12/2017 § 13 nr. 25 sammenholdt med nr. 31. Se også ordlisten som er bilag 2 og figur 2 på s. 6 i Rigsrevisionens beretning om kvotekoncentrationen i dansk fiskeri afgivet til Statsrevisorene August 2017. IOK-kvoteandelene gjelder for sild, makrell og industrifiske. FKAkvoteandelene omfatter torsk, flyndre (tunge), rødspette, hyse (kuller), kolmule, jomfruhummer, breiflabb (havtaske), reker, piggvar, mørksei og laks.

${ }^{48}$ BEK nr. 1604 af 19/12/2017 § 13 definition nr. 7.

${ }^{49}$ BEK nr. 1604 af 19/12/2017 § 91 stk. 1.
} 
myndighetskontroll med at flyttingen av kvoter innenfor et kalenderår ivaretar hensynet til et forsvarlig driftsgrunnlag for de involverte fartøy. For IOK slås det kort og godt fast at fartøyets samlede eierkrets kan overdra det avgivende fartøys kvoteandel helt eller delvis hvis eierne av mottakerfartøyene oppfyller vilkårene i $\S \S 7$ og 102. Sistnevnte bestemmelse gjelder kvotekonsentrasjon. Førstnevnte inneholder generelle bestemmelser om disponeringen av enkeltfartøys kvoteandeler.

b. Varighet. IOK og FKA er i utgangspunktet tidsubegrenset, men kan sies opp med 16 års varsel. ${ }^{50}$ Videre kan tilbakekall finne sted ved brudd på fiskerilovgivningen. ${ }^{51}$

c. Eksklusivitet. Fiskerimyndighetene har i prinsippet et relativt stort handlingsrom ved fordelingen av den nasjonale kvote. Det slås for eksempel fast i fiskeriloven $\S 34$ stk. $1 \mathrm{nr}$. at forvaltningen kan fastsette regler om den ervervsmessige utnyttelsen av ressurser, herunder om fordeling av de disponible fangstmengder med nærmere fastsatte kvoter for grupper av fartøy, enkeltfartøy eller redskapstyper. Her kan det vises til at det i bekjentgjørelsen for 2014-2020 fremkommer at andeler og ekstrakvoter fordeles før tildeling av årsmengde på grunnlag av enkeltfartøys FKA. ${ }^{52}$ Et formål som er ivaretatt gjennom denne fordelingsmekanismen, er å fremme førstegangsetableringer og yngre fiskeres deltakelse i fiskeriene gjennom fiskerifondet. ${ }^{53}$ Poenget her er at selv om definisjonene av FKA og IOK indikerer en eksklusiv rett til en andel av den nasjonale kvote, må dette forstås med den modifikasjon at myndighetene har et ikke ubetydelig handlingsrom.

d. Notoritet og publisitet. I Bekentgørelse 2014-2020 fremkommer at opplysninger om FKA og IOK er offentlig tilgjengelig. Det slås fast at fiskeristyrelsen skal føre et offentlig tilgjengelig EDB-register over overdragelige kvoteandeler (FKA og IOK). ${ }^{54}$ Ved overdragelse av IOK skal salgsprisen inngå i registeret. ${ }^{55}$ Når det gjelder registrering av pant i fartøy og fisketillatelser, er reglene om dette allerede antydet.

e. Noen fellestrekk. I det danske systemet står fartøyet sentralt, men fisketillatelsene og fartøyet er ikke uatskillelige. Det åpnes dermed for at tillatelsene overføres mellom fartøy gjennom salg eller ved utleie. I det norske systemet har vi sett at det er åpnet for overføring av spesielle tillatelser og deltakeradganger uavhengig av fartøyet tillatelsene er knyttet til. Kvoteutvalget foreslår videre å åpne for utleie av kvoter innenfor kvoteåret.

Ved eventuelt fjerning av tidsavgrensningen for deltakeradganger og strukturkvoter vil det norske systemet bevege seg mer i retning av det danske systemet hva angår varighet. Det norske systemet har

\footnotetext{
${ }^{50}$ BEK nr. 1604 af 19/12/2017 § 10.

${ }^{51}$ BEK nr. 1604 af $19 / 12 / 2017 \S 15$.

${ }^{52}$ BEK nr. 1604 af 19/12/2017 § 41.

${ }^{53}$ BEK nr. 1604 af 19/12/2017 § 53 stk. 1 nr. 3.

${ }^{54}$ BEK nr. 1604 af 19/12/2017 § 11. https://fiskeristyrelsen.dk/fiskeristatistik/statistik-for-fiskerietsregulering/.

${ }^{55}$ BEK nr. 1604 af 19/12/2017 § 12.
} 
imidlertid ikke en bestemmelse om adgang for fiskerimyndighetene til oppsigelse av individuelle kvoteandeler med 16 års varsel. Hos oss får imidlertid «alminnelige forvaltningsrettslige regler» om tilbakekall anvendelse, jf. deltakerloven $\S 11$, første ledd bokstav f. Videre kan samme lov $§ 19$ om tilbakekall og avgrensning av en hel gruppe spesielle tillatelser nevnes.

Tillatelsene gir i begge systemer en eksklusiv adgang til å høste av og tjene på fiskeressursene selv om det vil være mulig for fiskerimyndighetene fra et år til et annet å endre fordelinger av den nasjonale kvote, med den konsekvens at enkeltfartøys rett til høsting reduseres. ${ }^{56}$

Behovet for sikring av notoritet og publisitet er ivaretatt i begge systemer. ${ }^{57}$

\subsection{Lovfestingen i 2006}

Lovfestingen av adgangen til pantsetting av fisketillatelser i 2006 representerte en forenkling for næringen. Før dette var det nødvendig med registrering av pant i skipet i Skibsregisteret og pant i fartøyets fisketillatelser i Personbogen etter reglene om underpant i løsøre. ${ }^{58}$ Søloven $\S 47$ stk. $4-8$ lyder slik:

«Stk. 4. En rettighed over et skib, som er registreret i skibsregisteret, omfatter uden særlig vedtagelse fiskerirettigheder, der tildeles ejeren i sin egenskab af ejer af skibet eller erhverves af denne til brug for skibet. Dette gælder dog ikke, hvis erhvervelsen er sket i strid med stk. 6.

Stk. 5. Særskilte rettigheder over en fiskerirettighed, der omfattes af en rettighed over et skib, der er registreret i skibsregisteret, kan ikke stiftes eller forbeholdes, jf. dog stk. 6 og 7.

Stk. 6. Ejeren af et skib, der er registreret i skibsregisteret, kan med samtykke fra samtlige registrerede rettighedshavere afhænde en fiskerirettighed.

Stk. 7. Ejeren af et skib, der er registreret i skibsregisteret, kan uden samtykke fra rettighedshaverne i skibet overdrage retten til at udnytte en fiskerirettighed fra overdragelsestidspunktet og indtil kalenderårets udløb. Aftaler om begrænsning af ejerens beføjelser efter 1. pkt. er ikke gyldige.

Stk. 8. Fiskerirettigheder efter stk. 4-7 omfatter kvoteandele af enhver art, ret til årsmængde, havdage og kapacitet samt andre lignende rettigheder, der tilkommer den til enhver tid værende ejer af et skib, der anvendes til erhvervsfiskeri.»

\footnotetext{
${ }^{56}$ Se deltakerloven $\S 4$, siste ledd og havressurslova kapittel 3.

${ }^{57}$ Se deltakerloven $\S \S 22$ og 23.

${ }^{58}$ Se forslag 29. marts nr. 196 til lov om ændring af søloven og forskellige andre love, punkt 2.3.
} 
Det bestemmes i stk. 4 første punktum at rettigheter i et skip som er registrert i skipsregisteret, uten særskilt vedtakelse omfatter fiskerettigheter som er tildelt eieren i egenskap av eier av skipet, eller som erverves av eieren til bruk for skipet. Bestemmelsen er tuftet på at det er hensiktsmessig å belåne fartøyet og fisketillatelsene samlet. ${ }^{59}$ Etter lovendringen er registrering av pant i fisketillatelser i Personbogen bare aktuelt for fartøy som ikke kan innføres i Skibsregisteret, dvs. mindre fiskefartøy.

Lovendringen representerer utvilsomt en forenkling og klargjøring av retten til å pantsette fisketillatelser, jf. Bredholt mfl. som sier at endringen innebærer

«at en rettighed, herunder en registreret panterettighed og en søpanterettighed over et skib, som er registreret i skibsregisteret omfatter fiskerettigheder, som nærmere præciseret i stk. 8, der tildeles ejeren i sin egenskab av ejer af skibet eller erhverves af denne til brug for skibet». ${ }^{60}$

Det kan naturlig nok ikke stiftes eller forbeholdes særskilte rettigheter over fiskerettighetene i større utstrekning enn det som følger av stk. 6 og $7 .{ }^{61}$ Dette er slått fast i stk. 5. I tråd med stk. 6 kan kvoteandeler overdras til eie. Videre kan eier av fartøy i en begrenset periode overdra fiskerettigheten til et annet fartøy uten å innhente samtykke fra panthaver i skipet. ${ }^{62}$

Bredholt mfl. peker for øvrig på at fiskerettighetene har stor verdi, og at disse derfor har vesentlig finansieringsmessig betydning. Etter innføringen av omsettelige kvoteandeler har det funnet sted en fornyelse av den danske flåte samtidig som lønnsomheten er økt for fartøy over 15 meter. ${ }^{63}$ Tilsvarende utvikling kan også konstateres hos oss i fartøygrupper som omfattes av strukturkvoteordningene. ${ }^{64}$

\subsection{Vurdering}

Bestemmelsene i søloven $\S 47$ stk. 4-8 gir god veiledning hvis løsningen i «Barents Eagle» skal nedfelles i lovgivningen. Formuleringene er klare og i samsvar med rettstenkningen i denne dommen. Videre er det en del sentrale fellestrekk mellom det norske og det danske fiskerisystemet. Bestemmelsene sikrer også behovet for forutberegnelighet i kredittmarkedet. Det kreves selvsagt visse justeringer for tilpassing til dagens fiskerisystem. Utleie av kvoter innenfor kvoteåret er for eksempel ikke mulig i dagens system, jf.

\footnotetext{
${ }^{59} 1 . c$.

${ }^{60}$ Jørgen Bredholt (mfl.), Søloven med kommentarer, 4. utgave, 2012, s. 149.

${ }^{61}$ Bredholt (mfl.), op.cit., s. 150.

${ }^{62}$ Bredholt (mfl.), op.cit., s. 151.

${ }^{63}$ Rigsrevisionens beretning om kvotekoncentrationen i dansk fiskeri afgivet til Statsrevisorene August 2017, s. 7.

${ }^{64}$ Dag Standal og Frank Asche, «Hesitant reforms: The Norwegian approach towards ITQ’s», Marine Policy 88 (2018) s. 58-63, på s. 62.
} 
stk. 7. Videre må beskrivelsen av fiskerettigheter i stk. 8 endres. Vi har for eksempel ikke et system hvor «kapacitet» er en særlig rettighet. ${ }^{65}$

\section{Avsluttende merknad}

Drøftingen peker, som sagt, i retning av at løsningen i «Barents Eagle» bør lovfestes og at den danske søloven $§ 47$ kan vise vei. I denne avsluttende merknaden vil jeg for å gi et mer helhetlig bilde av flåteleddet peke på en sentral utfordring i norsk fiskeripolitikk etter at vi på kort sikt har løst kapasitetsproblemet. Det er hvordan rettferdig fordeling mellom nålevende generasjoner og mellom nålevende og fremtidige generasjoner skal ivaretas.

I dag er det slått fast at de viltlevende marine ressurser «ligg til fellesskapet», jf. havressurslova $§ 2$. Det må erkjennes at dagens fiskerisystem med lukkede fiskerier, omsettelige kvoter og et manglende system for innkreving av ressursrente ikke umiddelbart fremstår som rettferdig. Her kan også tilføyes at etter gjennomgang av den omfattende forskningen som foreligger om bruk av omsettelige fiskerettigheter på verdensbasis, er konklusjonen hos en gruppe forskere fra en rekke land at denne type systemer ikke er noe universalmiddel. ${ }^{66} \mathrm{Et}$ mulig første skritt for å ivareta hensynet til rettferdig fordeling er lovfesting av en oppsigelsesadgang for fisketillatelser og avskrivingsregler som innebærer at fiskebåteierne får tilbake sine investeringer. ${ }^{67}$ På lengre sikt etableres et system som har større grad av legitimitet blant folk flest enn det som synes å være tilfellet i dag. ${ }^{68}$

\footnotetext{
${ }^{65}$ Kapasitet måles i kW ut fra et fartøys bruttotonnasje og motorkraft. Se BEK 866 af 28/06/2017 Bekentgørelse om fartøjer, der anvendes til erhvervsmæssigt fiskeri i saltvand $\S 2 \mathrm{nr} .1$.

${ }^{66}$ Oran R. Young mfl., «Moving beyond panaceas in fisheries governance», Proceedings of the National Academy of Sciences of the United States of America PNAS, http://www.pnas.org/content/115/37/9065 (21.11.2018). Det er for eksempel god grunn til å stille spørsmål om bruk av omsettelige fiskerettigheter er veien å gå i kystflåten under 11 meter. Det vil si i den delen av flåten som vi gjerne omtaler som sjarkflåten. Se Nærings- og fiskeridepartementets høringsnotat om sjarkflåtens rolle i et fremtidsrettet kvotesystem. https://www.regjeringen.no/contentassets/1b919ec3e3594e65ae9bb0d6a3da2fe8/horingsnotatom-sjarkflaten-2203-2018.pdf.

${ }^{67}$ Se i denne sammenheng følgende tre grunnlovsforslag i Dokument 12 (2015-2016) fra hhv. Ingrid Heggø mfl, Torgeir Knag Fylkesnes mfl. og Per Olaf Lundteigen mfl. Det er her sistnevnte forslag som er mest interessant, ved at det skisseres en løsning for tilbakeføring av ressursrenten til fellesskapet.

${ }^{68}$ Se Audun Iversen (red.), Fisken og folket, 2016, kapittel 12.
} 